University of Louisville

ThinkIR: The University of Louisville's Institutional Repository

Electronic Theses and Dissertations

1948

\title{
A biochemical investigation of cirrhosis.
}

Mary Frank Beattie

University of Louisville

Follow this and additional works at: https://ir.library.louisville.edu/etd

Part of the Medicine and Health Sciences Commons

\section{Recommended Citation}

Beattie, Mary Frank, "A biochemical investigation of cirrhosis." (1948). Electronic Theses and Dissertations. Paper 1914.

https://doi.org/10.18297/etd/1914

This Master's Thesis is brought to you for free and open access by ThinkIR: The University of Louisville's Institutional Repository. It has been accepted for inclusion in Electronic Theses and Dissertations by an authorized administrator of ThinkIR: The University of Louisville's Institutional Repository. This title appears here courtesy of the author, who has retained all other copyrights. For more information, please contact thinkir@louisville.edu. 
A BIOCHEMICAL INVESTIGATION OF CIRRHOSIS

\author{
A Dissertation \\ Submitted to the Faculty \\ in Partial Fulfillment \\ of the Requirements \\ For the Degree of \\ Master of Science
}

\begin{abstract}
Department of Biochemistry
University of Louisville

School of Medicine
\end{abstract}

by

Mary Frank Beattie

1948 


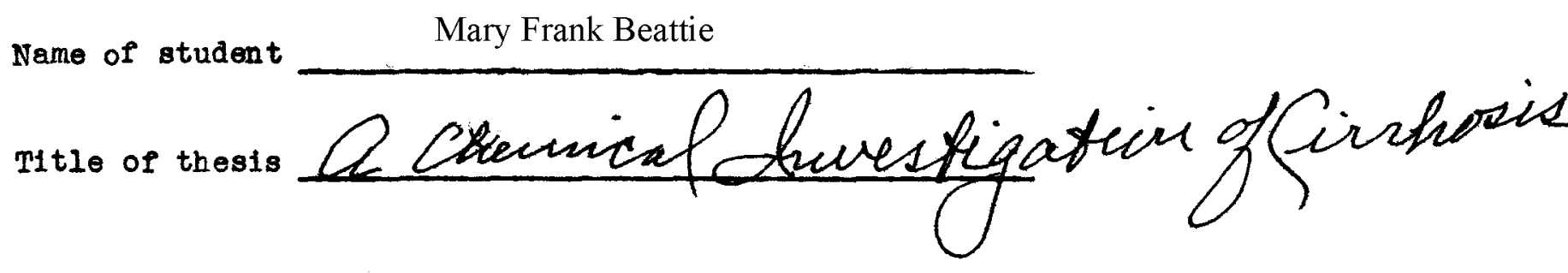

Approved by reading committee

composed of the following members:

A. W. Homberger

Edward J. Van Loon

A. J. Miller

Name of director

A. W. Homberger

Date $c-2-48$ 


\section{Introduetion}

Dr. Mann (1) has aptly described the liver as the "commlssariat of the body". Being the largest gland in the body, the liver engeges in a multiplieity of known functions and a probable host of unknown functions. Its described functions include hematopoletic processes, detoxification, reticuloendothelial functions, water balance, and the all important metabolism of food material to provide rapid utilizable energy for the tissues. The complexity and fluctuation of function must be amphasized in order to evaluate the accumulating mass of data concerning hopatic function. All the actirities of this organ are not affected to the same degree by a disease process. The functional status of the liver is dependent on the physiological or pathological status of a number of other organs. Damage up to elghty percent (2) does not cause abnormal results in liver funetion tosts performed upon experimental animals. Closely allied to the large reserve power is the remarkable regenerative power of the gland which may completely mask the pathological lesion. Diet, impaired renal function, or faulty intestinal absorption may also affect the results obtained in the various liver function tests. Hoffbauer and his co-workers (3) have recently polnted out the value of composite study of liver functions. Sereral 1nvestigators $(3,4,5,6,7,8)$ have made use of the liver biopsy in an attempt to correlate morphological change with impaired liver functions.

This peper presents a series of liver function tests made in conjunction with a micro-chomical and microscoplc examination of materiel obtained by liver biopsy. The function tests selected were based upon the secretory and excretory runctions of the liver, the detoxification process, and the roles played by carbohydrate, protein, and lipid metabolism in the diseased liver. The biopsies proved advantageous in studying the dynamics of the diseased liver when 
proper precautions were used. The precautions observed were:

a - contamination of the specimens with blood was reduced to a minimum;

b - tissue for chemical analysis was placed immediately in potassiun hydroside solution and tissue weight determined;

- - specimens for patbologlcal examination were placed in saline packs and sent to the laboratory for examination directly after the operations. Another adrantage of tissue analysis lay in the fact that samples could be obtained and studied at frequent intervals during $11 \mathrm{fo}$.

The hazards of random sampling were taken into account in evaluating the results. The biopsies were always performed at the same hour of the day, on patients in a fasting state, in order to arold the diurnal variations of 11ver glycogen (43). Gomorl and Goldner (44) adrocate great caution in judging the metabolic state of the liver on the besis of the glycogen content of biopsies. They obserted variations exceeding several hundred percent in samples taken from the same lobe of a rabbit's liver. While caution should be used in fudging the biopsy findings, variations of that degree are not expected in man (45); the rabbit has one of the greatest veriations of all experimentsl animals (46). Doane and his group (47), using rats, ran a series of micro-chemical liver glycogen determinations and found the difference in readings not to exceed four percent of their mean. These investigators also showed histologically that after six to twelve hours starvation (a period similar to that of our patients), glycogen is otill abundent and olther distributed evenly or concentrated peripherally in the lobules. Our micro-chemical glycogen results were checked against the pathologl st's report.

The data reported in this paper was obtained from sixteon patients at Louisville General Hospltal; the elinical diagnosis on these patients wes cirrhosis of the 11ver. Cirrhosis, by our definitign, is a chronic disesse characterized by 
degeneration of the liver parenchyma with fatty destruction and necrosis of the individual cells. There is fibrous tissue proliferation and subsequent regeneration of parenchymal cells resulting in a changed lobular and vascular pattern $(9,10)$.

\section{Methods}

1. Total Protein:

This abstance was determined on serum by a micro-Kjeldahl method amploying direct nesslerization. An appropriate correction for non protein nitrogen was applied (11). The procedure wes a modification of Wong (12) with peroxide replacing persulfate for the oxidation. A Oniversal Spectrophotometer was used to measure the density of the nesslerized solutions against an ammonium sulfate standard.

2. Albumin and Globulin:

The low temperature methenol precipitation of serum globulin as recommended by Pillemer and Hutchinson (13) was used. The results obtained by this method compare farorably with those obtained throvgh electrophoretic analyses. Sodium sulfate precipitation of globulins (Howe's method) led to quantitative inaccuracies in determination of albumin and globulin according to Pillemer and Hutchinson (13). Our laboratory verffied the reports of incomplete separation of albumin and blobulin when Howe's selting out method was employed.

3. Cephalin Cholesterol Flocculation Test:

This test was performed as outlined in Kolmer and Boerner (23). The results were graded from 0 to 4 t.

4. Thymol Turbidity Test:

The procedure described by Maclagen (24) was used. 5. Colloidal Gold Test:

Gray's method (25) was employed. 
6. Prothrombin:

The method of Quick as outlined in Kolmer and Boerner (27) was followed in determining prothrombin.

7. Cholesterol - Pres and total:

The Schoenhelmer-Sperry (21) procedure employing digitonin precipitation was used. 8. IIpese:

This enzyme wes determined by the method of Cherry and Crandall (26) who recommended the use of an olive oll emulsion as the substrate. .

9. Bromsulphalein test:

This test was performed according to the directions stated in Kalmer and Boerner (16). Then $1 \mathrm{cc}$, of dye per $10 \mathrm{~kg}$. of body weight was infected intrevenously, the test results were interpreted according to the following scale:

$10 \%$ or less dye retention at 30 minutes - no liver impairment

$$
\begin{array}{ll}
20 \% \text { - } 40 \% \text { dye retention } & \text { - slight impeirment } \\
50 \% \text { - } 80 \% \text { dye retention } & \text { - moderate impeirment } \\
90 \% \text { or greater dye retention } & \text { - severe impairment }
\end{array}
$$

10. Serum Bilirubin:

The method of Malloy and Erelyn (19) was employed.

\section{Hippuric Acid Excretion Test:}

Quick's intravenous modification was used $(17,18)$ in order to eliminate the factor of faulty intestinal absorption. The intrarenous infection contelned 1.77 en. of sodium benzorte (equiralent to 1.5 . of benzolc acid) dissolved in $20 \mathrm{ml}$. of distilled water.

12. Non Protein Nitrogen:

The Haden modification of a Folin-Wu protein-free filtrate (14) was used for the determination. An aliquot of this filtrete was used to determine the nitrogen 
according to the method of Koch and MoMeekin (15).

13. Anylase (Diestase):

This substance was determined by the incubation of serun according to a modifled somosyl (31) procedure. The reduction power of the enzymatic degradation products of the starch was determined using the glucose method described bitor. 14. Glucose:

Whole blood was deproteinized with zinc sulfate and sodium hydroxide (28). The new oopper reagent dereloped by Somogyi (20) was used to determine the reducing power of the glucose. Nelson's arsenomolybdate solution (30) wes employed as the chromogenic reagent.

\section{Galactose Toleranoe Test:}

The intravenous test was performed according to the directions of Bassett and Althausen (32) Glucose was removed from the blood samples by fermentation with yeast (33) and the filtrates were then analyzed for galactose.

\section{Glycogen:}

The biopsied liver, tissue was analyzed for glycogen according to the method described by Wagtendonk, et al (34) with the following modifications:

a - The precipitated glycogen was placed in a racuum dessicator orernight to insure 1ts complete dryness;

b - The glycogen-iodine color complex was developed over a thirty minute period In a constant temperature water bath (35). Proceeding biopsy analyses the Wagtendonk method was tested with guinea plgs. Twelve liver samples from these experimental enimals were enalyzed for glycogen content; 1 mg. of glycogen was added to each of twelve additional samples and adequate recorery was obtalned.

Since, in the Wagtendonk method, the tissue glycogen was compared againat 
a standard glycogen solution, the purity of that solution had to be determined. The standard contained $100 \mathrm{mg}$. of glycogen (Eastman Kodak Co.) dissolved in $100 \mathrm{cc}$. of $35 \%$ potassium hydroxide. The purity of the glyoogen was determined as follows: Glycogen was precipitated from $5 \mathrm{cc}$. of the standard solution (100 mg. \%) with 10-15 cc. of $95 \%$ ethanol as the precipitating agent. This reaction was continued orernight in Pyrex testtubes. Addition of a 1\% aqueous solution of sodium sulfate (36) seemed unnecessary to insure cemplete precipitation. The tubes were contrifuged at high speed, the supernatant decanted, and the alcohol fumes expelled by heat or aspiration in a racuum dessicator. The precipitated elycogen was subject to acid hydrolysis with $6.7 .5 \mathrm{cc}$. of normal hydrochloric acid $(2.2 \%)$ for a two hour period in a bolling water bath. Sahynn and Alsberg (37) have determined that hydrolysis with normal hydrochloric acid is completed in two hours. It is important to replace the liquid boiled off during hydrolysis in order to prevent charring. Sahyun (38) used $t$ in foil to cover the mouth of the test tube while Good, Kramer, and Somogy1 (39) recommended an air conđenser. We found the addition of a few drops of water at thirty minute intervals prevented any signs of charring. sjogren and his group (40) have clearly demonsttated the effect of acid concentration on the hydrolysis of glycogen as shown in the following graphs: Mg. of glycogen $\quad \mathrm{Mg}$ of glycogen

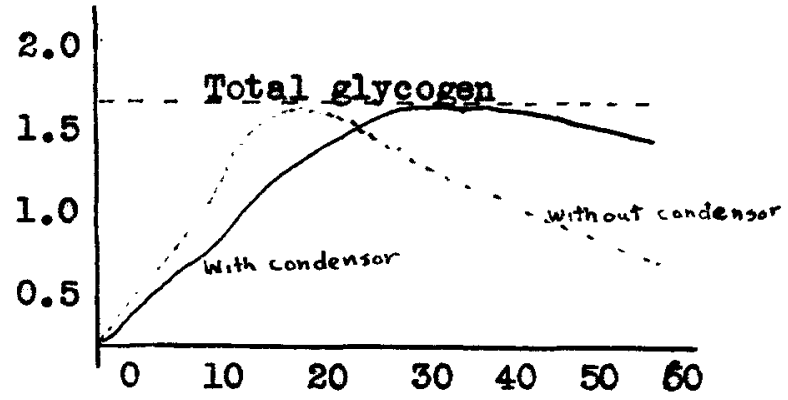

Time in minutes

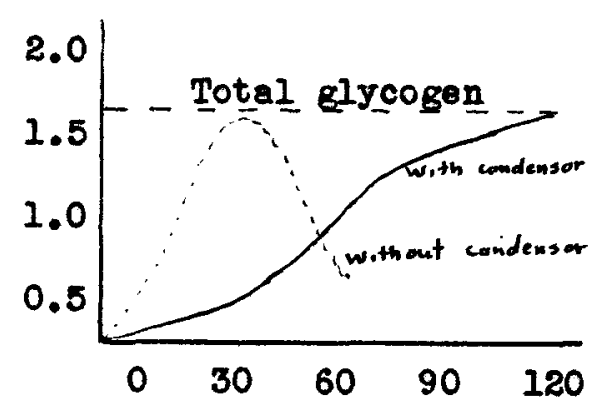

Time in minutes
Fig. I - Hydrolysis of glycogen with $5 \mathrm{~N}$ sulfuric acid
Big. II - Hydrolysis of glycogen with $0.75 \mathrm{~N}$ sulfuric acid 
The acid hydrolysate was transferred to a $50 \mathrm{ml}$. volumetric flask with washing and neutralized with normal sodium hydroxide using phenolphthalein as the indicator. The sample was then made up to rolume with distilled water. Allquot portions $(2 \mathrm{ml}$.$) of this solution were tested for glucose content according to$ the Somozyi method previously mentioned. The results were calculated with the following formula:

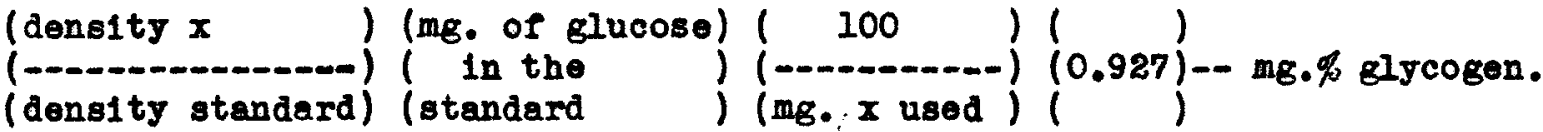

The purity was ascertained to be $98.17 \%$ and this figure was rechecked eight times. We retained the theoretical factor 0.927 for the conversion of glucose values to glycogen al though Nerking (4I) has questioned its validity. He argues, on the basis of experimental evidence, that the factor should approach 0.95 , but no definite conclusions have been reached.

The classie principles laid down by peluger were followed in the tissue analyses - e.e.

1 - degtruction of tissue by alkal1, the glycogen remaining unaffected;

2 - precipitation of the gljoogen;

3 - hydrolysis of the precipitated glycogen to glucose and subsequent determination of the amount of glucose by a standard sugar technique.

According to the reports of Seandinavian investigetors (42), the normal value for glycogen from exclsed 11 ver tissue was found to be 6-7\%, They reported values of $5.6 \%$ glycogen upon analysis of liver tissue from cirrhotic patients. A three day perlod was required to complete all the various liver function tests and biochemical determinations on a single patient. 
Test

Total protein $\ldots \ldots \ldots$

Albunin . . . . . . . .

Globulin _............

A/G ratio $\ldots \ldots \ldots$

Cephalin cholesterol flocculation - -

Colloldal gold - . . . . . -

Thymol turbidity $\ldots+\ldots$

Prothrombin _...........

Total cholesterol _........

Free cholesterol _. . . . .

Cholesterol esters _........

Lipese $\ldots \ldots+\ldots$

Brom sulphalein dye excretion - . -

Bilirubin ..............

H1ppuric acid synthesis - . - .

Nonprotein nitrogen - . . . . -

Amylase - . . . . . . . .

Glucose - . . . . . . . . .

Galactose tolerance test .....

Glycogen _. . . . . . . -
Normal renge

$6.5-8.5 \mathrm{gm} \%$

$4-5 \sin \%$

$1.5-2.5 \mathrm{gm}$

$1.5-2.5$

$0-14$

curves not exceeding an initial value of 4

$0-4$ units

$80-100 \%$ (elotting time $12-13$ seconds)

$110-390 \mathrm{mg} \%$

$70-230 \mathrm{mg} \%$

$60-70 \%$

$0.2-1.0 \mathrm{cc} N / 20$ sodium hyaroxide

$10 \%$ or less dye retention in 30 minute specimen

$0.1-0.5 \mathrm{mg} \%$

0.7 sodiun benzoate excreted in 1 hour

$20-40 m g \%$

$80-180 \mathrm{mg} \%$

$70-100 \mathrm{mg} \%$

0 - $30 \mathrm{mg} \%$ gelactose in 75 minute specimen

$6-7 \%$ 


\section{Discussion of Results}

\section{A- Proteins:}

The liver is intimately concerned with the formation of the blood proteins although other tissues of the body appear to synthesize, particularly the globulin fraction. Therefore, in hepatic dys function changes in the quantity and the quality of the protelns would be expected. Electrophoretic studies (48) confirm the fact that atriking increase in the gamma globulin fraction is one of the most consistent findings in cirrhosis. In conjunction with other investigators $(49,50,51,52)$ wo find a striking and consistent reversal of the A/G ratio. The decreased production of albumin (the smallest molecular weight blood protein) results in an absolute increase of gemma, beta, and alphe globulins (larger molecular wolght fractions). This reversal of ratio, when considered with other test results, is raluable in diagnosing the amount of parenchymal damage (53) in a hepatic disease process. However, alteration of the ratio within itself has no specific value, since such alteration can occur in the extra-hepatic damage.

Whe total protein appears to stay within normal limits in cirrhosis. The slightly high value found in case 4 might be explained on the basis of the great increase in serum globulin or dehydration.

B-Specific tests for gamma globulin:

This series of test includes cephalin cholesterol flocculation, thymol turbidity, and colloidal gold which give positive reactions in the presence of increased serum gamma globulin.

The cephalin cholesterol flocculation test was developed by Hanger in 1938 (22, 70). Electrophoretic studies (72) proved that gamma globulin isolated from normal and pathological sere showed marked cephalin flocculation activity. Hanger found that the degree of flocculation peralleled roughly the severity of the 
process in c1rxhosis and was negative in those instances where residual scarring was apparently the sole lesion. Our results compare farorably with those obtained by Hanger as may be seen from the following table:

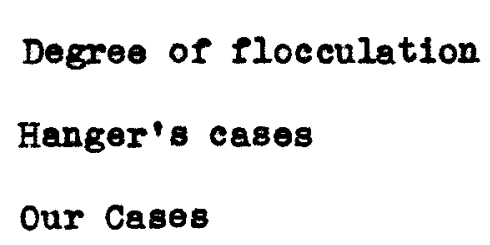

\begin{tabular}{c|c|c|c|c}
$4+$ & $3+$ & $2+$ & $1+$ & 0 \\
\hline 15 & 8 & 11 & 2 & 10 \\
\hline 1 & 6 & 13 & 5 & 3
\end{tabular}

The test is simple to perform and reliable results can be obtained. The test is an index of active parenchymal damage rather than measure of residual function (91). Grey (73) described the colloidal gold test in 1940. The test depends upon qualitative change in the gama globulin frection and adition of electrophoretically separated albumin inhibits the reaction. In accordance with Gray we found the test remarkably sensitive yielding positive results in every case. However the technical details associated with preparation, standardization, and acidiflcation of the gold solution render the test a difficult one to perform.

The newest of the flocculation tests is the thymol turbidity reported by Maclagen in 1944 (74). Again positive results depend upon the presence of increased gamme globulins. The test indicates acute liver damage and does not measure the degree of this involvement (75).

In several of our cases the thymol was active after the cephalin cholesterol flocculation had subsided indicating that two different activity processes were probably responelble for the positive results. Franklin and his group (76) contend that the thymol turbidity test 18 closely related to 11 ver cell regeneration but our results do not confirm this idea. C - Prothombin:

This protein is found in the globulin fraction of plasma and can be synthesized In the liver in the presence of vitamin $K$. Therefore impairment of liver function 
should result in a decrease in the prothombin level of the blood. Our results do not show this. However, the test controls are inedequate requiring a standard to be run each time on "normal" blood. We recommend that quick's test be replaced with the test which determines prothombin time and response to vitamin $K$ therapy. The latter test is more sensitive and reliable in our opinion.

D - LIpid Metabolism:

The development of more accurate mothods for the determination of cholesterol have increased investigation in the relation of the liver to cholesterol metabolism. There is still a great deal of controversy on the subject but experimental evidence (65) points to the important role played by the liver in the intermediary metabolism of 11poids. Th1s organ appears to possess the power of remoring cholesterol from the blood, storing 1t, and probably synthesizing the compound. The liver is considered to be an active regulator of blood cholesterol and cholesterol esters. Several factors (68) influence the blood cholesterol level:

1 - diurnal variation;

2 - diet;

3 - age.

Greene and his group (66) have prepared the following chart illustrating our present knowledge of cholesterol metabolism:

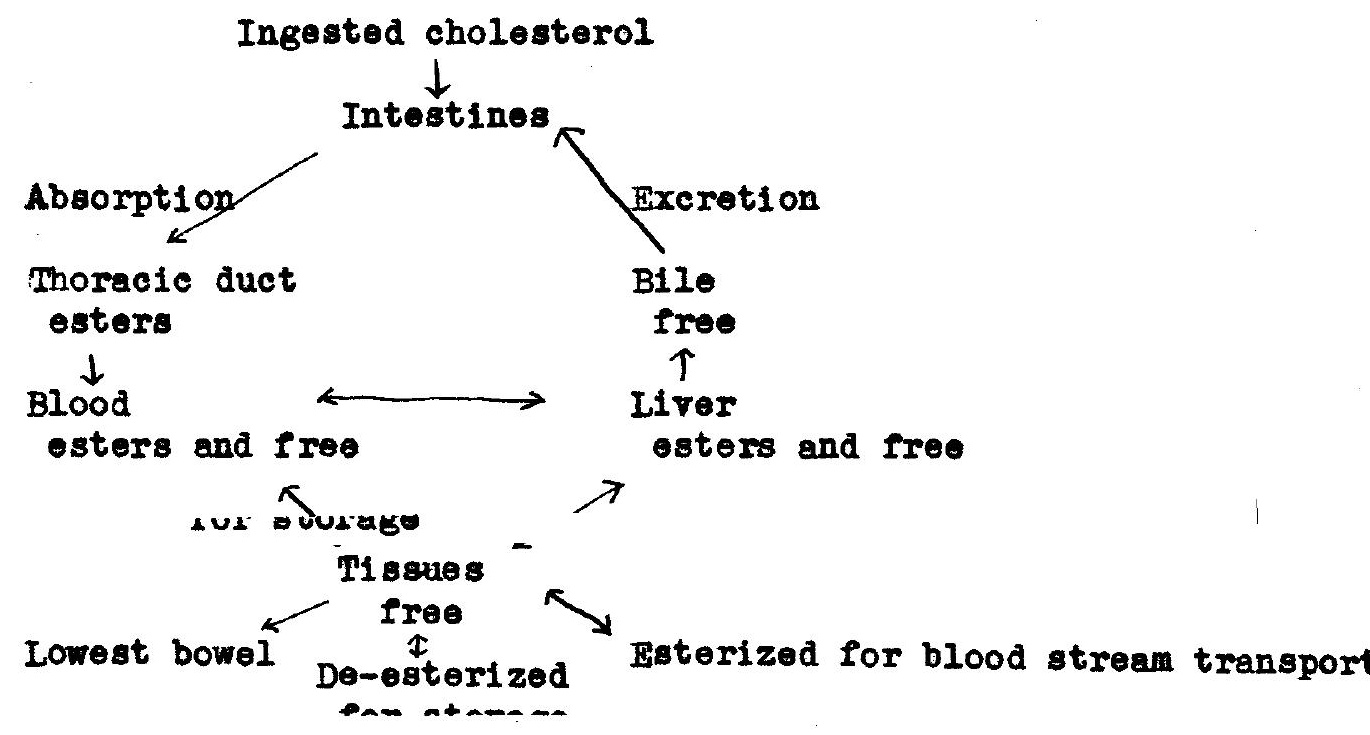


Many investigators $(66,67)$ have found that in the presence of hepatic in jury the cholesterol esters of the blood are reduded in amount or entirely absent. Th1s seems to be true in acute diseeses but not in the chronic processes - cirrhosis. In our results only two cases out of sixteen show a slightly lowered blood cholesterol ester level. Epsteln (69) has reported a hyper cholesterolemia, both total and ester, observed in regeneration and healing of the diseased liver. Case 6 in our series may be an example of this healing effect.

The enzyme lipese was also investigated. In $25 \%$ of our cases a rise was exhibited indicating pancreatic involvement associated with hepatic damage. E- Bxcretory function tested with bromsulphalein dye:

In 1924 Rosenthal (54) studied the physiological behavior of varfous halogenated phthelein dyes. These dyes when infected intravenously were removed by the liver and excreted in the bile. Continued research led Rosenthal and White (55) to the conclusion that the sulfonated phenoltetrahalogen phthalein group of dyes was the most satisfactory and of this group bromsulphalein possessed the best test requi rements. Positive results obtained with this test indicate impaired liver function. However, Rosenthel warns that, while test results may be interpreted quantitatively from a function standpoint, the relation between function and extent of pathological lesion may be widely divergent depending on the type of lesion and its duration. This is particularly true in chronic liver disease where regeneration of cells may partially restore hepatic function, although diffuse scar tissue mey be present. Our results 1llustrate this effect; only $12.5 \%$ of our cases demonstrated moderately severe hepatic damage by the bromsulphalein test. However, our other laboratory results indicate a much lerger percentage would be expected to show decreased excretion of the dye.

Soffer (56) explains that the dye is excreted speciftcally by the liver, 
although perhaps not quentitatively as there is some evidence that the reticuloondothelial system is capable of taking up the dye. The test is relatively easy to perform and presents interesting evidence of liver regeneration in our groupN. B. cases 2 and 3. However Rosenthal's method has been criticized because of its lack of sensitivity (57). Macdonald (58) recommends a serial bromsulphalein test and graphically depicts the limitations of the thirty minute test based upon experimental evidence:
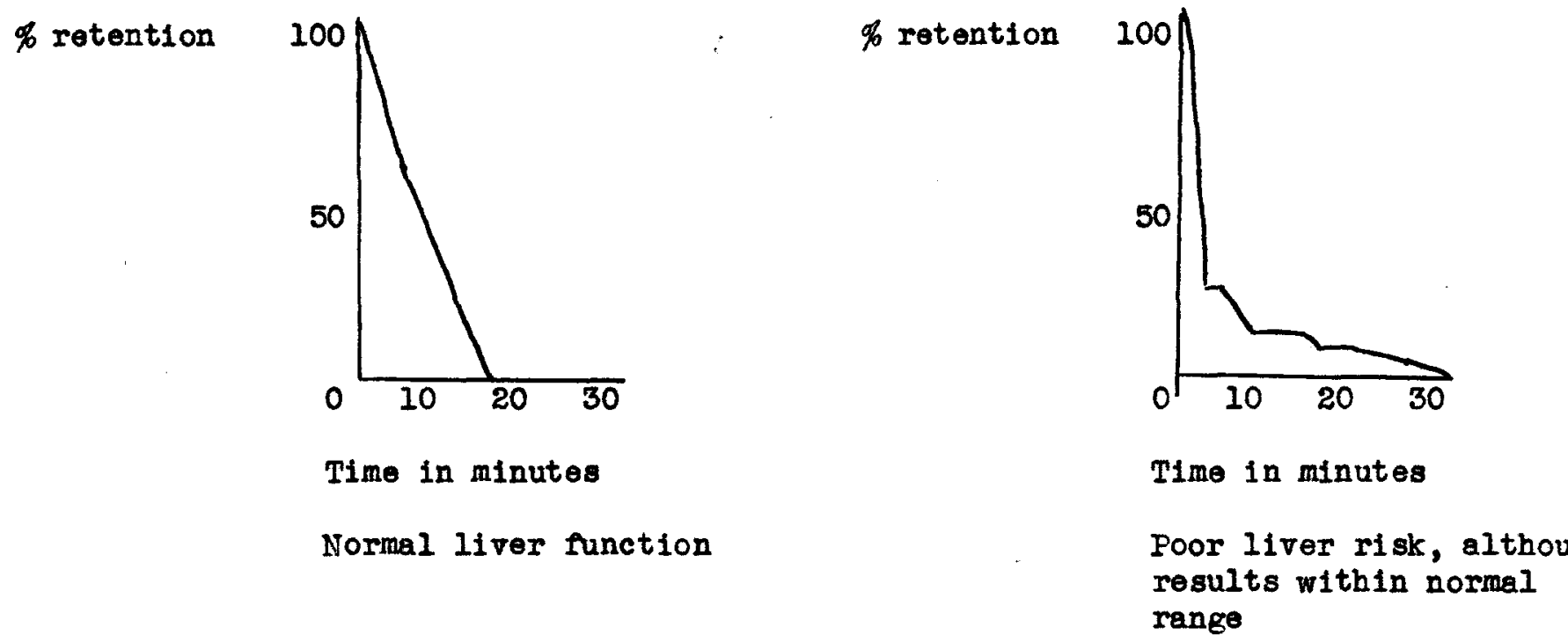

F-Secretory function of the liver:

The Kupfer cells of the liver are generally conceded to be the site of formation of bilirubin from hemoglobin. The liver epithelial cells function to excrete into the bile canaliculae the bilirubin carried by the blood stream. All of these mechanisms seem to escape severe damage in cirrhos1s. Although the serum bilirubin showe slight elevation from time to time, a merked increase has not been observed in this series of cases.

G - Detoxification mechanism of the liver:

In numerous publications $(59,60)$ Quick has published reports dealing with the conjugation of benzoic acid and glycine to form hippuric acid. In 1938 Quick (6I) reported an intravenous modification which seemed to be more sensitive in detecting liver damage. He demonstrated that only the first hour urinary excretion of hippuric 
acid measures the maximan capacity of the normal liver to synthesize this substance; the second hour excretion contained much smaller amounts of hippurte acid. However in the diseased liver the rexerse is true.

This test measures a metabolic as well as detoxification process occurring in the 1iver. The rate of hippurte acid formation is dependent primarily on the rate of glycine synthesis by the liver. White and his co-workers (62) have stated thet the mechanism of Hippuric acid synthesis seems to have little reserve and is easily upset. We have found this to be true and our results were similar to those reported by Hoffbauer et al (63) in a study of cirrhosis.

While the test has been sensitive and reliable in the hands of others (64), many factors influence the results. Complete cooperation on the part of the petient is required. Also conditions of dehydration (often seen in cirrhosis) and kidney involvement may retard the elimination of synthesized hippuric acid and result in low output.

\section{G- Nonprotein nitrogen:}

During the course of the disease the non proteln nitrogen shows slightly increased values in our reports. A signiflcant increase is noted in the terminal stages of the disease denoting decreased renal function.

H - Carbohydrate metabolism:

Experimental evidence indicates that galactose is metabolized specifically by the liver and that the conversion of galactose to glycogen is not dependent upon the action of insulin $(77,78,79,80,81)$. Therefore galactose is the sugar of choice for testing the glycogenic function of the liver.

Since the liver slowly converts small amounts of the suger to glycogen, decreased tolerance to this substance is observed in the presence of hepatic damage. In agreement with the results of Bessett and Althausen (81), our data 1llustrates decreased galactose tolerance in the majority of our cirrhosis patients. Makted 
hyperclycemia, indicating a decreased gelactose tolerance, correlates with the Impalred glycogenic function, found upon chemical determination of glycogen in biopsied liver specimens in our series of ceses. The galactose tolerance test appears to be a sensitive indicator of the glycogenic capacity of the Iiver. Blood glucose wes determined in order to observe any correlation between blood sugar level and liver glycogen. It is interesting to note that increased blood glucose values paralleled decressed glycogen biopsy results. This might indicate that the liver is still capable of synthesizing and mobilizing glycogen but uneble to store it (82). It would be interesting to determine whether blood lactate increases in conjunction with the increase in glucose level and decrease in liver glycogen.

Determination of anylase provided no aditional information concerning the functionel state of the diseased liver.

Glycogen is generally considered to be the reserve palysaccharide of the animal world, although its presence has been demonstrated in certain bacterla and fung1. Determination of liver glycogen by chemical analyses of biopsied tissue offers valuable information concerning the effect of disease upon the 11ver and particularly upon the storage of this carbohydrate in the liver.

Claude Bermard first reported the existence of glycogen in 1856 and dereloped a method for its quantitative determination (83). Subsequent modification and improvement of the method by PIluger and others has resulted in the present accurate and relatively simple micro-procedure.

The molecular structure of glycogen has been subjected to intensive investigation $(84,85,86,87,88,89,90,91,92,93)$. In the glycogen molecule the glucose residues are linked in cheins by the $\alpha 1-4$ glycosidic bond and the more stable $\propto$ 1-6 glycosidic bond. These chains appeared to be arranged in a highly branched structure as indicated by the red-brown color that the poly- 
saccharide gives with iodine. Experimental evidence shows that iodine color reactions with polysaccharides: are dependent upon the degree of branching and chain length of the polysaccharide. A blue color represents a relatively unbranched chain and a red color corresponds to a highly branched molecule.

Meyer has proposed the multiple brenching theory to depict the ramiIled structure of glycogen. His theory is based upon analysis of the nolecule

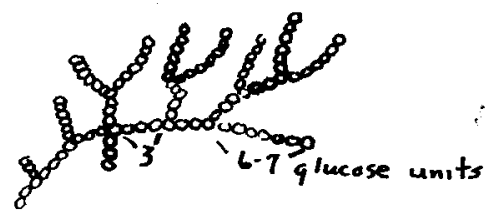

Structure of glycogen according to Meyer

by methylation and enzymatic degradation. Employing the Haworth and Hurst and group assay method, mothylated glycogen has been found to contain one terminal glucose unit per eleven gluccse residues. Glycogen is then subjected to attack by B-amylase and $47 \%$ of the molecule is degraded. The residual dextrin is again assayed and found to contain $18 \%$ terminal groups - ie, one terminal group per 5.5 glucose units. This date provides evidence for the compact structure of the residual dextrin with 1 ts multiple branching. The intact glycogen molecule contains exterfor branches of 6-7 glucose units.

Since interior and exterior brenches in the molecule are short, glycogen lends itself to a more compact structure which is spherical in shape as has been verified experimentally with the ran't Hoff laws of osmotic pressure. The size of the native molecule is indicated by its large molecular weight which is in excess of four million.

Glycogens ingested in the diet are probably broken down completely into glucose by the amyleses and glucosideses of the digestive tract. Glycogens are also degreded by $\propto 1-4$ and $\alpha$ 1-6 phosphorylases. In the presence of inorganic phosphate and glycogen, the phosphorylase enzymes catalyze the reaction by which 
orthophosphoric ecid cleaves the glycosidic linkages and yields glucose-1-phosphete. An intramolecular phosphate transfer to glucose-6-phosphate is then aided by the enzyme phosphoglucomutase.

Phosphorolysis is reversible the direction of the reaction being determined by the relative concentrations of glucose-1-phosphate and inorganic phosphate. The remoral of inorganic phosphate favors glycogenesis while its addition hastens glycogenolysis. In the intact animal the removal of phosphate is accomplished by the oxidation of carbohydrate which is coupled with the regeneration of AIP and so permits the phosphate donor to be used orer again in the hexokinase reaction.

The synthesis and breakdown of glycogen is affected by many factors $(94,95,96,97,98,99,100,101,102,103,104,105,106,107,108,109,110)$. Only a few of these factors will be considered in this paper.

Cori has demonstrated, in vitro, that the synthesis of a polysaccharide from monosaccharides requires the presence of a small amount of the polysaccharide and that the process involves a bullding up of chains and branches.

$$
\begin{aligned}
& \text { glucose-1-phosphate }+ \text { terminal glucose unit (of glycogen) } \text { phobphate } \\
& \propto 1-4 \text { glycosidic chain unit of } \\
& \text { polysaccharide }
\end{aligned}
$$

In adition to reaction kinetics, the hormonal belance of the body influences glycogenesis and glycogenolysis. Stetten has determined that adrenalin stimulated anaerobic glycolysis in the muscle with subsequent liberation of lactic acid which is utilized for glycogenesis in the liver. He further determined that the deposition of glycogen in the muscle is farored by insulin. The reason for this reaction can be explained on the basis of corl's work. Cori showed that the first step in tissue utilization of glucose -

1e, glucose + ATP hexokinase glucose-6-phosphate + ADP is inhibited by the action of an anterior pituitary extract upon the hexokinase reaction and that this inhibition is opposed by insulin. 
The close integration of carbohydrate metabolism with fat and protein metabolism has been verifled with isotopic studies. A simplified presentation of the inter-relation is depicted in the following diagrem:

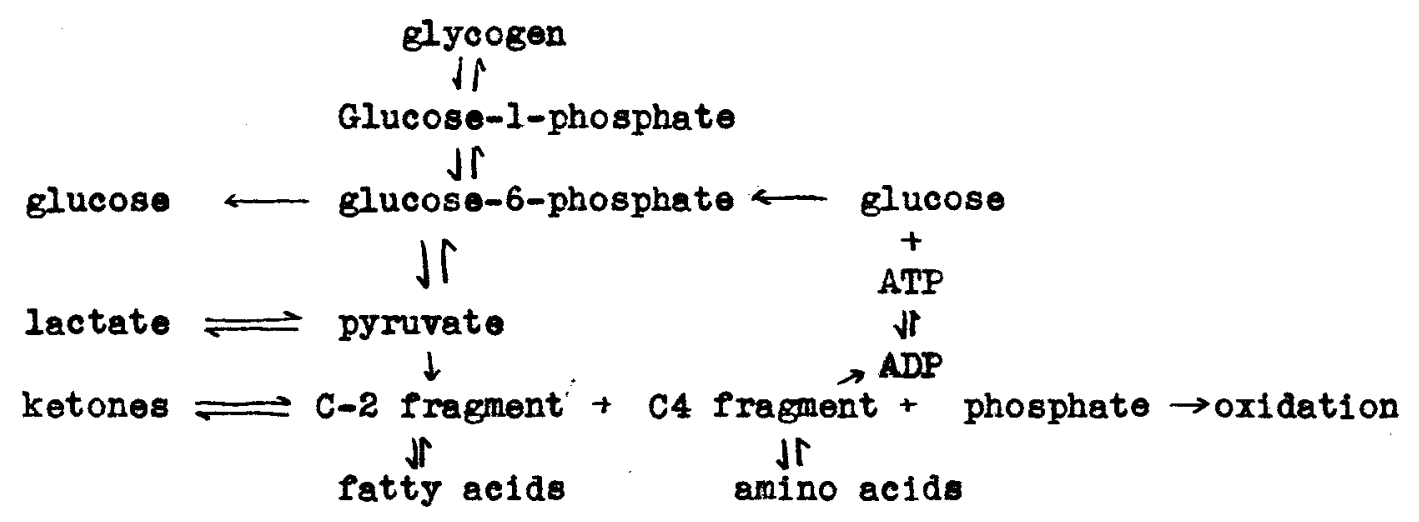

We feel that continued chemical studies of l1ver glycogen w1ll contribute much valuable information concerning the function of the normel and pathological 1iver. Due to the various inter-relationships involved in the synthesis and storage of glycogen, we belleve that greater insight into body metabolism in diseased states can be obtained. Howerer, glycogen determinations alone can not validate any hepatic diagnoses but they must be considered in relation to other tests of liver functiois. Investigation of metabolic diseases in a manner similar to the procedures outlined in this paper offers untold opportunities to further the knowledge of abnormal body metabolism.

Within the limits imposed by the study of a small number of cases, we believe that liver glycogen assay affords a sensitive indication of existing hopatic pathology. However we were unable to obtain any biopsies just prior to death and therefore could not investigate this hepatic pathology and compare it with post mortem findings. Continued efforts in this field will probably furnish further insight into general body metabolism and additional data in order to secure better clinical diagnosis. 
Case 1 - C.T. (m.w.) age 43

Chemlcal reports:

Total protein

$1-9-48 \quad 3-15-48 \quad 3-17-48 \quad 4-12-48$

$8.3 . \mathrm{m} \% \quad 6.8 \mathrm{gm}$

Albumin

$2.8 \mathrm{gm} \% \quad 1.6 \mathrm{gm} \%$

Globulin

$5.5 \mathrm{gm} \%$

A/G rat10

0.5

0.3

Cephelin cholesterol flocculation 2+

$2+$

$2+$

84

Colloidal gold

55443211

Thymol turbidity

5.2 units 3.5 units 3.5 units 5.6 units

Prothrombin $70.9 \%$

Totel cholesterol

$316.8 \mathrm{mg} \%$

Free cholesterol

$81.6 \mathrm{mg} \%$

Cholesterol ester

$74 \%$

IIpase

Bromsulphalein dye - $\underset{n}{\operatorname{natention}} 30 \mathrm{~min}$.
$60 \mathrm{~min}$.
$3 \%$

B111rubin

$1.7 \mathrm{mg} \%$

Hi ppuric acid

0.07 gm sodium benzoste

Nonprotein nitrogen

$37.6 \mathrm{mg} \% \quad 214.8 \mathrm{mg} \%$

Anylase

Glucose

$76.4 \mathrm{mg} \%$

Galactose tolerance

Glycogen

6.9\%approx. $2.8 \%$ 
Pathological reports:

First biopsy (1-9-48) specimen showed considerable increase in fibrous connective tissue; remaining liver cells quite granular and swollen.

Diagnosis: c1rrhosis, portal

Second biopsy $(3-15-48)$ no pathological specimen

Death occurred 4-16-48 (hemorrhage) 
Case 2 - I.B. (m.W.) age 56

Chemical reports

Total ptotein

Albumin

Globulin

A/G ratio

Cephalin cholesterol flocculation

Colloldal gold

Thymol turbidity

Prothrombin

Total cholesterol

Free: cholesterol

Cholesterol ester
$1-13-48$

$6.8 \mathrm{gm}$

$2.08 m \%$

$4.8 \mathrm{gm} \%$

0.4

21

553211

5.0 units

$128.4 \mathrm{mg} \%$

$51.1 \mathrm{mg} \%$

$60 \%$
$2-9-48$

7.7 gmo

2.4 gm\%

$5.3 \mathrm{gm} \%$

0.5

12

3.2 units

$176.0 \mathrm{mg} \%$

$40.0 \mathrm{mg} \%$

$77 \%$

0.5 ec sodium hydroxide

II pase

Retention $30 \mathrm{~min} .2 .5 \%$

$60 \mathrm{~min}$. negative $n$

$0.7 \mathrm{mg} \%$

B1lirubin

H1ppuric acid

Non protein pitrogen

Anylase

Glucose

Gelactose tolerence

Glycogen

$$
0.5 \mathrm{mg} \%
$$

$0.16 \mathrm{gm}$ sodium benzoste

$41.9 \mathrm{mg} \%$

$94.3 \mathrm{mg} \%$

$66.5 \mathrm{mg} \%$

60 min.

$75 \mathrm{~min}$.
$42.9 \mathrm{mg} \%$

$33.5 \mathrm{mg} \%$

5.2\% (approx.)
0.05 gm sodium benzoste $44.9 \mathrm{mg} \%$

$80.2 \mathrm{mg} \%$

$103.3 \mathrm{mg} \%$

$60 \mathrm{~min} . \quad 31 \mathrm{mg} \%$

$75 \mathrm{~min}$. $13.4 \mathrm{mg} \%$ 
Pabhological Reports: First blopsy (1-13-48) report was cirrhosis with acute degeneration. Appearence of some of the cells suggested regeneration.

Second biopsy (2-9-48) was unsuccessful. Howerer ascitio fluid wes examined and no cancer cells were found.

Note the improvement of the liver functions dye excretion and carbohydrate metabolism in the chemical tests (2-9-48) which would suggest some cellular regeneration as reported by the pathologist (1-13-48). 
Case $3-J_{.} S_{.}\left(m_{0} w_{0}\right)$ Age 52

Chemical reports

Total protein

Albumin

Globulin

NG ratio

Cephalin cholesterol flocculation

Colloidal gold

Thymol turbidity

Prothrombin

Total cholesterol

Free cholesterol

Cholesterol ester

IIpase
$1-13-48$

$7.3 \mathrm{gm} \%$

$2.18 \mathrm{gm} \%$

$5.2 \operatorname{gon} \%$

0.4

$1+$

543211

4.2 units

$-\infty$

$168.4 \mathrm{mg} \%$

$53.2 \mathrm{mg} \%$

$68 \%$
$2-9-48$

7.18

$2.3 \mathrm{gm} \%$

$4.8 \mathrm{gm} \%$

0.5

trace

2.1 units

$156.0 \mathrm{mg}$

$42.9 \mathrm{mg} \%$

$72 \%$

0.5 ce sodium hydroxide

Bromsulphalein dye - 30 min.retention $28 \% 30$ min.retention $5 \%$ $60 \mathrm{~min}$. retention $17.8 \% 60 \mathrm{~min}$. retention $3 \%$

Bilirubin

Hippuric acid

Mon protein nitrogen

Amylase

Glucose

Calactose tolerance

Glycogen

$$
0.9 \mathrm{mg} \%
$$

031 em sodium benzoate

$42.5 \mathrm{mg} \%$

$77.6 \mathrm{mg} \%$

$88.0 \mathrm{mg} \%$

75 min.

$48.6 \mathrm{mg} \%$

$60 \mathrm{~min}$.
$1.3 \mathrm{mg} \%$

$0.06 \mathrm{gm}$. sodium benzoate

$83 \mathrm{mg}$

$47.0 \mathrm{mg} \%$

$149.2 \mathrm{mg}$

$75 \mathrm{~min}$.

$60.8 \mathrm{mg} \%$

$44.9 \mathrm{mg} \%$

4.7\% (approx.) 
Pathological reports: First biopsy (1-13-48) showed acute degeneration of the liver. Slight amount of fibrous connective tissue present; liver cells were very granular in appearence. Second biopsy (2-9-48) report was increased fibrosis. Diagnosis: moderate cirrhosis of the l1ver.

An increase in liver damage can be seen in second series of chemical tests and 18 in accord with the interpretation of the pethologist. Death occurred $3-15-48$. 
Case 4 - E.G. (m.w.) Age 48

Chemical Reports:

Total protein

Albumin

Globulin

A G ratio

Cephalin cholesterol flocculation

Colloldal gold

Thymol turbidity

Prothrombin

Total cholesterol

Free cholesterol

Cholesterol esters

Iipase

Bromsulphalein dye $-30 \mathrm{~min}$. retention
$60 \mathrm{~min}$. retention

Bilirubin

Iippuric acid

Non protein nitrogen

Anylase

Glucose

Galactose tolerance

Glycogen
$1-20-48$

9.1 gn\%

$3.0 \mathrm{gm} \%$

$6.1 \mathrm{gm} \%$

0.5

trace

5542211

6.7 units

$116.5 \mathrm{mg} \%$

$54.7 \mathrm{mg} \%$

$53 \%$

$47 \%$

$33.8 \%$

$0.6 \mathrm{mg} \%$

$0.08 \mathrm{gm}$ sodium benzoate

$-$

$62.1 \mathrm{mg} \%$

$104.6 \mathrm{mg} \%$

$60 \mathrm{~min}$.

$35.4 \mathrm{mg} \%$

$5.9 \%$ (approx.) 
Pathological reports: F1rst biopsy specimen (1-20-48) contained large amounts of fibrous connective tissue. Cytoplasm was granular and appeered to be undergolng degenerative change. Interpretation: cirrhosis; fatty liver.

Both chemical and pathological reports indicate activity. Although the cephalin cholesterol flocculation test is negative, the thymol turbidity test indicetes an active process in the diseased liver. Hippuric acid synthesis and albuminrglobulin ratio results show hepatic dinfunction. 
Case 5 - D.G. (m.w.) Age 7

Chemical Reports:

$1-28-48$

Total protein

6.8 gm\%

Albumin

$2.9 \mathrm{gm} \%$

Globulin

$3.9 \%$

A/G ratio

0.7

Cephalin Cholesterol

negative

Collo1dal Gold

54321

Thymol Turbidity

2.8 units

Prothrombin

Total cholesterol

$128.5 \mathrm{mg} \%$

Free Cholesterol

$66.7 \mathrm{mg} \%$

Cholesterol esters

$48 \%$

Iipase

Bromsulphalein dye - $30 \mathrm{~min}$. retention

None

Bilirubin

$0.5 \mathrm{mg} \%$

Hippuric Acid

0.095 sodium benzoate

(recovered after injection of $0.44 \mathrm{gm}$ )

Nonprotein Nitrogen

$35.3 \mathrm{mg} \%$

Anylase

$48.6 \mathrm{mg} \%$

Glucose

$89.4 \mathrm{mg} \%$

Gelactose Tolerance - 60 minutes

$34.1 \mathrm{mg} \%$

75 minutes

$26.5 \mathrm{mg} \%$

Glycogen

first specimen

$5.9 \%$

second specimen

$4.7 \%$ 
Pathological Reports: First biopsy specimen (1-28-48) contained excessire amounts of fibrous connective tissue. Loss of normel cell architecture with swelling and granularity was reported. Interpretation: cirrhosis (early, portal); acute degeneration (severe)

Clintcal diagnosis: Deton1-Fancon1 syndrome

Note degree of involvement suggested by albumin-globulin ratio and colloidal gold tests. The functions of dye excretion and hippuric ac1d synthesis appear normal. 
Case 6 - H.B. (m. ...)

Chemical Reports:

$2-18-48$

Total proteln

$8.18 m \%$

Albumin

$3.3 \mathrm{gm} \%$

Globulin

$4.8 \mathrm{gm} \%$

A/G ratio

0.7

Cephalin cholesterol

12

Colloidal Gold

Thymol Turbidity

3.5 units

Prothrombin

$85.4 \%$

Total Cholesterol

$328.0 \mathrm{mg} \%$

Free Cholesterol

$89.8 \mathrm{mg} \%$

Cholesterol esters

$73 \%$

If pase

0.4 ce sodium hydroxide

Bromsulphalein dye - 30 min. retention $4.0 \%$

$60 \mathrm{~min}$. retention None

B111rubin

$0.3 \mathrm{mg} \%$

Hippuric Acid

$0.1 \mathrm{gm}$ sodium benzoate

Nonprotein Nitrogen

$47 \mathrm{mg} \%$

Amylase

$163.7 \mathrm{mg} \%$

Glucose

$131.1 \mathrm{mg} \%$

Gelactose Tolerance - 60 minutes

$63.3 \mathrm{mg} \%$

$27.8 \mathrm{mg} \%$

Glycogen

$2.1 \%$ 
Pathological Reports: No specimen

The results of the function tests indicate a cirrhotic condition with no active lesion at the time of testing. The biopsied glycogen assay and hippuric acid synthesis are very low. Normal results obtained in the bromsulphalein test might indicate some regeneration. Negative cephalin cholesterol flocculation and thymol turbidity tests indicate no active lesion at the time of testing. 
Case 7, C.R. (m.w.) Age 71

Chemical reports:

$2-24-48$

$3-.25-48$

Total protein

$8.5 \mathrm{gm}$

$6.9 \mathrm{gm} \%$

Albumin

$2.4 \mathrm{gm} \%$

2.1 gm\%

Globulin

$6.1 \mathrm{gm} \%$

$4.8 \mathrm{gm} \%$

$A / G$ ratio

0.4

0.4

Cephalin Cholesterol

22

22

Collo1dal Gold

543211

Thymol Turbidity

4.5 units

3.9 units

Protirrombin

$89 \%$

$91.2 \%$

Total Cholesterol

$-\infty$

$123.5 \mathrm{mg} \%$

Free Cholesterol

$33.2 \mathrm{mg} \%$

$38.2 \mathrm{mg} \%$

Cholesterol esters

$-\infty$

$69 \%$

Lipase

1.0 ce sodium hydroxide

Bromsulphalein dye - $30 \mathrm{~min}$. retention 60 min. retention

$27.5 \%$

30 min. retention $-23 \%$

$15 \%$

$60 \mathrm{~min}$. retention $-9 \%$

Bili rubin

$1.3 \mathrm{mg} \%$

$0.9 \mathrm{mg} \%$

Hi ppuric Aeld

$0.04 \mathrm{gm}$ sodium benzoate $0.02 \mathrm{gm}$ sodium benzoat

Nonprotein Nitrogen $-\infty$

$71.9 \mathrm{mg} \%$

$125.9 \mathrm{mg} \%$

$107.3 \mathrm{mg} \%$

$81.1 \mathrm{mg} \%$

$1.6 \%$ $189.6 \mathrm{mg} \%$

$126.7 \mathrm{mg} \%$

$120.8 \mathrm{mg} \%$

Gelactose Tolerance - 60 minutes 75 minutes

Glycogen
60 min. -

75 min. -

$89.9 \mathrm{mg} \%$

$74.4 \mathrm{mg} \%$

$1.9 \%$ 
Pathological reports: First biopsy specimen (2-24-48) showed perilobular fibrosis. Individual liver cells showed granular cytoplasm and in some areas cell borders were indistinct. Cytoplasm contained large fat racuoles in moderate amount. Second biopsy $(3-15-48)$ showed all liver cells with a marked degree of swelling and granularity. There was slight diffuse fat infiltration. A moderate amount of fibrous connective t1ssue was reported. Interpretation: cirrhosis, portal; fatty liver. 
Case 8, 0.G. (m.w.)

Chemical Reports

Total protein

Albumin

Globulin

A/G ratio

Cephalin cholesterol

Collo1dal Gold

Thymol Turbidity

Prothrombin

Total Cholesterol

Free Cholesterol

Cholesterol Esters

Iipase

Bromsulphalein dye

Bilirubin

Hi ppuric Acid

Nonprotein Nitrogen

Amylase

Glucose

Galactose Tolerance

Glycogen
$2-19-48$

$2-24-48$

$7.7 \mathrm{gmo}$

$1.2 \mathrm{gm} \%$

$6.5 \mathrm{~mm}$

0.18

32

22

553211

4.9 units

5.6 units

$89.4 \%$

$$
\begin{array}{ll} 
& 155.7 \mathrm{mg} \% \\
& 48.9 \mathrm{mg} \% \\
& 69 \% \\
& 0.8 \mathrm{cc} \text { sodium hydroxide } \\
30 \mathrm{~min} . \text { retention }- & 21 \% \\
60 \mathrm{~min} . \text { retention }- & 10 \% \\
& 0.6 \mathrm{mg} \% \\
& 0.02 \mathrm{gm} \mathrm{sodium} \mathrm{benzoste} \\
& 111.3 \mathrm{mg} \% \\
& 142.5 \mathrm{mg} \% \\
60 \mathrm{minutes}- & -2- \\
75 \mathrm{minutes}- & 130.9 \mathrm{mg} \% \\
& 104.8 \mathrm{mg} \%
\end{array}
$$$$
-
$$ 
Pathological Reports: No blopsy obtained.

Note function impairment of hippuric acid synthesis, carbohydrate metabolism and dye excretion. As the cephalin cholesterol flocculation activity decreases the thymol turbidity activity increases. The albumin is dangeroubly low. Death occurred $3-15 m 48$. 
Case 9, C.B. (m.พ.) Age 64

Chemical Reports 2-19-48

$2-26-48 \quad 3-9-48 \quad 3-15-48$

Totel protein

$8.5 \%$

$8.4 \mathrm{gm} \%$

Albumin

1.8 gm\%

$2.5 \mathrm{gm} \%$

Globulin

6.7 gm\%

$5.9 \mathrm{gm} \%$

A/G ratio

0.27

0.4

Cephalin Cholesterol 3 \&

32

32

21

Collo1dal Gold

553211

Thymol Turbidity 6.0 units

5.2 units 6.4 units 7.1 units

Prothrombin

$76.1 \%$

$90 \%$

Total Cholesterol

$108.7 \mathrm{mg} \%$

$188.2 \mathrm{mg} \%$

Free Cholesterol

$26.4 \mathrm{mg} \%$

$47.9 \mathrm{mg} \%$

Cholesterol esters

$76 \%$

$75 \%$

Lipase

2.9 cc sodium hydroxide -..-

Bromsulphalein dyo - 30 min. retention 60 min. retention

$33.5 \%$

$19.5 \%$

30 min. retention - $22.5 \%$

$1.4 \mathrm{mg} \%$

$0.7 \mathrm{mg} \%$

$0.1 \mathrm{gm}$ sodlum benzoate

$4021 \mathrm{mg} \%$

$0.04 \mathrm{gm}$. sodium benzoste

Nonprotein Nit rogen

Amylase

$181.3 \mathrm{mg} \%$

$61.7 \mathrm{mg} \%$

Glucose

Galactose Tolerance - 60 minutes

Glycogen

\section{5 minutes}


Pathological Reports: Birst biopsy (2-26-48) section showed liver cells with considerable granulation and irregularity in size. Large groups of liver cells, belleved to be lobules, were surrounded by a considerable amount of fibrous connective tissue.

Second biopsy $(3-15-48)$ contained liver cells which showed large amount of cloudy swelling and considerable loss of detail. Interpretation: cirrhosis, severe; acte degeneration

Note correlation between pathological and chemical reports. Second series of function tests indicete slight improvement of hepatic function. 
Case 10, R.G. (m.w.) Age 44

Chemical Reports:

$2-26-48$

$3-9-48$

Total protein

$6.8 \mathrm{gm} \%$

Albumin

$2.6 \mathrm{gm} \%$

Globulin

$4.2 \mathrm{gm} \%$

M/G Ratio

0.6

Cephalin Cholesterol

22

3

Colloldal Gold

32211

53321

Thymol Turbidity

3.5 units

6.4 units

Prothrombin

Total Cholesterol

$245.2 \mathrm{mg} \%$

Free Cholesterol

$51.1 \mathrm{mg} \%$

Cholesterol esters

$79 \%$

I1 pase

6.2 ce sodium hydroxide

Bromsulphale in dye - 30 min. retention $10 \%$

$60 \mathrm{~min}$. retention $2.5 \%$

B1lirubin

Hippuric acid

0.2 godium benzoate

Nonprotein Nitrogen

$56.7 \mathrm{mg} \%$

Amylase

$149.1 \mathrm{mg} \%$

Glucose

$160.3 \mathrm{mg} \%$

Galactose Tolerence - 60 minutes

$127.1 \mathrm{mg} \%$

$43.4 \mathrm{mg} \%$

Glycogen 
Fathological Reports: First biopsy (2-26-48) section showed a considerable amount of granularity and irregularity in size of liver cells. Nuclei were quite large suggesting regeneretion. Densely scattered fat cells apparently caused considerable atrophy of the liver. Interpretation: fatty liver. Clinical diagnosis: cirrhosis.

Chemical reports indicate severe involvement of the liver with decreased runction in protein and carbohydrate metabolism and hippuric acid synthesis. The flocculation tests (3-9-48) indicate increased activity of the hepatic lesion. 
Case II, G.B. (m.w.)

Chemical reports:

$4-21-48$

Total protein

$7.6 \mathrm{gm} \%$

Albumin

$3.9 \mathrm{gm} \%$

Globulin

$3.78 \%$

A/G ratio

I.I

Cephalin Cholesterol

$1+$

Colloidal Gold

. Thymol Turbidity

2.1 units

Prothrombin

$100 \%$

Total Cholesterol

Free Cholesterol

Cholesterol esters

IIpase

0.6 cc sodium hyaroxide

Bromsulphalein dye $-30 \mathrm{~min}$. retention $20 \%$ $60 \mathrm{~min}$. retention $10 \%$

Bilimain

$1.5 \mathrm{mg} \%$

Hippuric Acid

$0.05 \mathrm{gm}$ sodium benzoate

Nonprotein Nitrogen

$68.4 \mathrm{mB} \%$

Amylase

$81.3 \mathrm{mg} \%$

Glucose

$78.1 \mathrm{mg} \%$

Galactose Tolerance - 60 minutes

75 minutes

$5.6 \mathrm{mg} \%$

$2.9 \mathrm{mg} \%$

Glycogen

$5.5 \%$ 
Summary and Conclusions

1. The dyeogen assay in conjunction with the albumin-globulin ratio and galactose tolerence were found to be the most sensitive chemical tests indicative of liver pethology in this series of cases.

2. Pathological reports of cellular abnormality corresponded in a large number of cases with low glycogen values obtained from biopsies.

3. The colloidal gold test was positive in all cases.

4. Cephalin cholesterol flocculation and thymol turbidity tests showed episodes of spesmodic activity throughout the course of the disease.

5. Hippuric acid synthesis seemed to indicate a great loss of heaptic function In many of the petients but this did not correlate with the amount of damage as shown by the bromsuphalein test.

6. Total protein, amylase, prothrombin and bili rubin remained within nomel range. Non protein nitrogen increased in the terminal stages of the disease probably due to logs of renal function.

7. Determination of glycogen in biopsied liver specimens provided a useful method for the continued study of the diseased organ durante vivo.

The author wishes to express her thanks to Dr. B. J. VanLoon, Dr. A. J. Miller and Dr. Herbert Clay for their guldance and cooperation throughout the project. The author also wi shes to express her gratitude to Dr. A. W. Homberger, whose sanction made this project possible. 


\section{Bibliography}

1. Mann, F. C., Am. J. Digest, Dis. \& Nutrition, 4:355, 1937-38

2. Thomas, I. J., N. Ann. District of Columbia, 16:599, 1947

3. Hoffbauer, F. W., Ivans, G.T., \& Watson, C.J., M. Clin. North America, 363,1945

4. Davis, W. D., Scott, R.N., \& Lund, H.Z., Am. J. Med. Sci., 212:449, 1946

5. Franklin, M., Dopper, H., Skigmann, F., \& Kozell, D., Froc. Instit. Ned. Chicago, $16: 421,1947$

6. Neefe, J. R., Gestwoenterology, 7:1, 1946

7. Sherlock, S.F.V., J. Fath. \& Bact., 58:523, 1946

8. Rabson, S. M., Amer. J. Digest, Dis., 15:7, 1948

9. Wells, R. I., N. Arn. District of Columbia, 15:540, 1946

10. Detwe1ler, H. K., In R.I. Cecil (ed) Textbook of Wedicine, p. 760,

Philadelphia: พ. B. Saunders Co., 6th ej., 1943

11. Hawk, F. B., Oser, B. I., \& Summerson, w. H., p. 547, Philadelphia: The Blakiston Co., I2th ed., 1947

12. Jong, S. Y., J. Biol. Chem., 55:427, 1923

13. Pillemer, I., \& Hutchinson, M. C., J. Biol. Chem. 158:299, 1945

14. Jaden, R. I., J. Biol. Chem., 56:469, 1923

15. Koch \& Lclfeekin, J. Am. Chem. Soc., 46:2066, 1924

16. Kolmer, J. A., \& Boerner, F., p. 234, New York: D. Appleton-Centugy Co., 4 th ed., 1945

17. Quick, A. J., Aner. J. Digest, Dis., 6:716, 1939-40

18. KDlmer, J.A., \& Boerner, F., op. cit., p. 232

19. Nalloy, H. T, and Brelyn K.A., J. Biol. Chem., 119:4El, 1937

20. Hawk, Oser \& Sumerson, op. cit., p. 531 
21. Schoenteimer, R., \& Sperry, H.1., J. Biol. Chem., 106:745, 1934

22. Tanger, F. L., Tr. Assoc. Amer. Physicians, 53:148, 1938

23. Kolmer \& Boerner, op., cit., p. 236

24. Naclagen, N. F., Nature, 154:671, 1944

25. Gray, 3. J., Arch. Int. Ned., 65:524, 1940

26. Cherry, I.S., and crandall, I.A., Froc. Soc.Fxper. Biol. and Ned., $28: 572,1931$

27. Quick, A. J., from Kolmer \&oemer, p. 101, Jour. A.A.A., 110:1658, 1938

28. Somogzi, M., I. Biol. Chem., 160:069, 1945

29. Somogy1, M.., p. 61

30. Nelson, N., J. Biol. Chem., 153:375, 1944

31. Somogy1, H., J. Biol. Chem., 125:401, 1938

32. Passett, A.I., and Althausen, T.I., Amer. J. Digest, Dis., 8:432, 1941

33. Raymond, A.I., and Blanco, J.G., J. Biol. Chem., 79:649, 1928

34. Van Wagtendork, H. J., Simonsen, D.H., \& Fackett, P.I., J. Biol. Chen., $163: 301,1946$

35. Morris, D.I., J. Biol. Chem., 166:199, 1946

36. OsterberE, A.E., J. Biol. Chem., 85:97, 1929

37. Sahyan, N., \& Alsberg, C.I., J. Biol. Cheri., 93:235, 1931

38. Sahyan, M., J. Biol. Chem., 93:227, 1931

39. Good, C.A., Kramer, H., \& Somogyi, M., J. Biol. Chem., 100:485, 1933

40. Slogren, B., Nordengkjold, 'T., \& Holmgren, H., \& Mollerstrom, J., Arch. Ges. Fhysiol., 2404430, 1938

41. Nerking, J., Arch. ges. Fhysiol., 85:320, 1901

42. Verghougt, A.P.M., A.J. Ch. Heex 
44. Gomori, G., \& Goldner, M.G., Proc. Soc. Exper. Biol. \& Med., 66:163, 1947

45. Vergheugt, A.P.M., op. cit.

46. Swensson, A., reference froni C.A. 40:2879 4 , Acta. Physiol. Scand., $11: 158,1945$

47. Deane, H.W., Nesbett, F.B., \& Hastings, A.B., Froc. Soc. Ixper. Biol. \& Med., 63:401, 1946

48. Gray, S.J. \& Barran, E.S.G., Jour. Clin, Invest., 22:191, 1943

49. Cantarar, A., Amer. Jour. Clin. Fath., 8:142, 1938

50. Neyers, W.K., \&. Keefer, C.S., Arch, Int. Ned., 55:349, 1935

51. Tumen, H., \& Bockus, H.I., Amer. Jour. Med. Sci., 193:788, 1937

52. Nade, I. J., Amer. Jour. Clin. Path., 16:426, 1946

53. Franklin, H., Kozoll, D., on. cit., p. 421

54. Hosenthal, S.M., J. Pharmacol. \& Ixper. Therap., 23:385, 1924

55. Rosenthal, S.M., \& white, E.C., J.A.H.A., 84:1112, 1925

56. Soffer, I.J., ined., 14:186, 1935

57. Morrison, L.H. and Swalm, 7.A., Rev. Gastroenterol,, 7:269, 1940

58. HacDonald, D., Canad. Mied. Assoc. J., 39:556, 1938

59. Quick, A. J., J. Biol. Chem., 92:65, 1931

60. Quick, A. J., Arch. Int. lifed., 57:544, 1936

61. Quick, A. J., Am. J. Digest. Dis., 6:716, 1939-40

62. White, F.M., Deutsche E., \& Madock, S., Am. J. Digest, Dis., 7:3, 1940

63. Hoffbauer, F. H., Watson, C. J., op. cit., p. 371

64. Natier, J. G., Baltz, J., Marion, D.F., \& Hollands, R.H., Am. J. Digest, Dis., $9: 13,1942$

65. Epstein, 叉.Z., Rev. Gastroenterol., 4:12, 1937 
66. Greene, C.F., Hotz, R., \& Leahy, E., Arch. Int. Wled., 65:1130, 1940

67. Cantarow, A., Internat1. Clin. 7:257, 1935

68. Bruger, li., \& Somack, I., J. Biol. Chem., 97:23, 1932

69. Ipstein, I.Z., \& Greenspan, E.E., Arch. Int. Ned., 58:860, 1936

70. Hanger, F.M., Tr. Assoc. Amer. Fhysicians, 53:148, 1938

71. Rosenberg, D.H., \& Soskin, S., Amer. J. Digest. Dis., 8:421, 1941

72. Kabat, E.A., Fenger, F.J., Moore, D.H., C Landow, H., Jour, Clin. Invest., $22: 563,1943$

73. Gray, S.J., Arch. Int. Nied., 65:524, 1940

74. Naclagen, N.F., Nature: London, 154:671, 1944

75. Kunkel, H. G., Amer. Jour. Ked., 4:201, 1948

76. Franklin, M., Kozoll, D., op. cit., p. 421

77. Stetten, D., J. Diol. Chem., 159;123, 1945

78. Roe, J. H., Embartzman, A.S., Amer. Jour. Hed. Sc1., 186:425, 1933

79. Bollman, J.L., Fower, M.F. \& Miann, F.C., Proc. Staff lieet. Nayo Clinic, $6: 724,1931$

80. Foster, G. I., J. Biol. Chem., 55:291, 1923

81. Holmes, E.G., \& Trowell, H.C., Lancet, 265:395, 1948

82. Bassett, A.M. \& Althausen, T.I., op. cit., p. 433

83. Bermard, C., p. 553, Paris, France, 1877

84. Cori, C.J., \& Hassid, W.Z., Fed. Proc., 4:226, 1945

85. Cori, G.T., Swanson, M.A., \& Cori, C. J., ibid, p. 234

86. Swanson, M.A., \& Cori, C.J., I. Biol. Chem., 172:797, 1948

87. Swasson, l.. A., ibid, p. 805

88. Cori. C. J. \& Swanson, M.A., ibid, p. 815

89. Swanson, M.A., Ibid, p. 825 
90. Sillen, G.L., \& Myrbach, K., from C.A., 39:22467, 1945, Svensk. Kem. Tid., $55: 294,1943$

91. Meyer, K.H., from C.A., 37:91, 1943, Natur. Wissenschaften, 29:287, 1941

92. Meyer, K.P., Adv. Enzymol., 3:109, 1943

93. Lazaraw, A., Arch. Biochem., 7:337, 1945

94. Cori, C. J., Ted., Proc., 4:226, 1945

95. Meyer, K.H., ibid, pp. 126-132

96. Cor1, C.J. \& Cori, G.T., Ann. Rev. Biochem., 15:193, 1946

97. Steffen, D., Ann. Rev. Biochem., 16:125, 1947

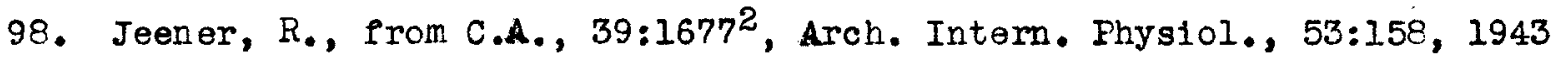

99. Fuhrman, F.A., \& Field, J., Arch. Biocbem., 6:342, 1945

100. Frice, W.H., Cor1,f.F. \& Colwick, S.P., J. Biol. chem., 160:633, 1945

101. Therk1scher, E. \& Werthe1mer, E., J. Fhys101., 100:385, 1942

102. Nertheimer, Z., J. Physiol. 103:359, 1945

103. Musrkischer, .., \& Wertheimer, R., J. Physiol. 104:361, 1946

104. Russell, J.A., \& Rernett, I.I., Am. J. Physiol. 118:196, 1937

105. Bennett, L.I., Ferkins, R.z., Indocrinology, 36:24, 1945

106. Stetten, D., \& Klein, B.V., J. Biol. Chem., 159:593, 1945

107. Stetten, D., \& Bayer, G.D., J. Biol. Chem., 155:231, 1944

108. Boyer, G.2., \& Stetten, D., I. B1ol. Chem., 155:237, 1944

109. Cori, C. F., The Harvey Lectures, $41 ; 253,1945-46$

110. Soskin, S. \& Levine, R., University Chicago Press: Chicago, 1946 